\title{
ENVIRONMENTAL CHANGE, SANITATION AND BUBONIC PLAGUE IN LAGOS, 1924-31
}

OLUKAYODE A. FALEYE

Department of History \& International Studies,

University of Ilorin, Nigeria

\section{Abstract}

The literature on the plague in Lagos focuses primarily on the impact of the epidemic on urban planning and social inequality. While the need for town planning was conceived during the outbreak, the implementation of major urban planning schemes in the port city was delayed till the post-plague years due to the global economic depression. Thus, the existing studies are restricted to the aftermath of the epidemic. In advancing this discourse, this paper examines the place of environmental change and sanitation in plague outbreak and control between 1924 and 1931. The approach is historical, based on the critical analysis of colonial administrative, meteorological, sanitary and medical records, as well as newspaper reports. This paper concludes that, while the scourge was combated through transborder epidemic surveillance, quarantine and medical interventions, sanitary measures were directly responsible for its termination in 1931. This brings to the fore the place of nature and culture in managing emerging infectious diseases such as Ebola in West Africa.

Keywords: bubonic plague, colonial interventions, disease processes, sanitary measures, Lagos

\section{Introduction}

The coming of European colonialists coincided with the emergence of serious epidemics in West Africa due to new patterns of urbanisation, demographic transition and sociocultural organisation. Whereas Europeans visiting the West Coast of Africa up to the nineteenth century had died in droves due to poor immunity to tropical diseases, ${ }^{1}$ their incursion facilitated the introduction of new types of diseases as the region witnessed outbreaks of the influenza pandemic ${ }^{2}$ as well as the plague

1 Philip D. Curtin, Disease and empire: The health of European troops in the conquest of Africa (Cambridge University Press, 1998), 4-11.

2 'Annual Report, Nigeria' (1918), 18. National Archives of Nigeria, Ibadan (NAI). 
in the first quarter of the twentieth century. ${ }^{3}$ As noted by Kalala Ngalamulume, the outbreak of the plague in West Africa was the latest in the series of epidemics that had ravaged the region since the second half of the nineteenth century. ${ }^{4}$ While earlier outbreaks had occurred in Senegal and the Gold Coast (now Ghana), the interconnectivity of British West Africa made the eventual transmission of plague from Kumasi (Gold Coast) to Lagos (Nigeria) through seaborne trade inevitable by 1924.

The first official case of the disease was diagnosed in Lagos on 28 July $1924 ;^{5}$ earlier unofficial cases were independently noticed by the natives. ${ }^{6}$ This scenario was greeted by diverse colonial and local responses. While the existing literature has been preoccupied with the politics of town planning and slum clearance following the plague years, ${ }^{7}$ this paper examines the nexus between environmental transformation and plague in colonial Lagos.

\section{Mapping the outbreak}

The bacterial agent that causes bubonic plague is Yersinia pestis, transmitted through contacts with infected fleas and rodents. ${ }^{8}$ A critical examination of the pattern of plague morbidity and mortality in colonial Lagos suggests that its rapid spread cannot be divorced from three factors - migration, population growth and environmental change. The first quarter of the twentieth century witnessed immigration and consequent population growth in the port city. ${ }^{9}$ The establishment of Lagos as the capital created employment for Africans seeking work, as well as acting as a stimulus

\footnotetext{
3 William J. Simpson, Report on Plague in the Gold Coast in 1908 (London: J. \& A. Churchill, 1909), 2; Liora Bigon, 'A History of Urban Planning and Infectious Diseases: Colonial Senegal in the Early Twentieth Century', Urban Studies Research (2012): 7, doi.org/10.1155/2012/589758; Myron Echenberg, Plague ports: The global urban impact of bubonic plague, 1894-1901 (New York: New York University Press, 2007), 5; Myron Echenberg, Black Death, White Medicine: Bubonic Plague and Politics of Public Health in Colonial Senegal (Oxford: James Currey, 2002), 15-52; Myron Echenberg, 'Plague in Africa: Third Pandemic', in Encyclopedia of Pestilence, Pandemics and Plagues, vol. 1: A-M, ed. J. P. Byrne (London: Greenwood, 2008), 487-91.

4 Kalala Ngalamulume, 'Plague and Violence in Saint-Louis-du-Sénégal, 1917-1920', Cahiers d'études africaines 183 (2006): 539, doi.org/10.4000/etudesafricaines.6027.

5 'Plague in Lagos'. From the Deputy Director of Sanitary Service, Lagos, to the Director of the Medical and Sanitary Service, Lagos. Memorandum No. 333/DMS/24 of 30 July (1924), 1-2. CSO 2613001 Vol. I, NAI.

6 'Report on Plague in Lagos-Southern Nigeria', Director, Medical Research Institute, Yaba, to the Director of the Medical and Sanitary Service, Lagos. Ref. 48/MRI/24 of 9 September (1924), 1. CSO 2613001 Vol. II, NAI.

7 Liora Bigon, 'Bubonic plague, colonial ideologies, and urban planning policies: Dakar, Lagos, and Kumasi', Planning Perspectives (2015), doi.org/10.1080/02665433.2015.1064779; Liora Bigon, 'Between Local and Colonial Perceptions: The History of Slum Clearances in Lagos (Nigeria), 1924-1960', African and Asian Studies 7 , no. 1 (2008): 49-58.

8 Robert D. Perry and Jacqueline D. Fetherston, 'Yersinia pestis—etiologic agent of plague', Clinical Microbiology Reviews 10 (1997): 35-66.

9 Ayodeji Olukoju, 'Population Pressure, Housing and Sanitation in West Africa's Premier Port-City: Lagos, 1900-1939’, The Great Circle 15, no. 2 (1993): 94.
} 
to the local economy, drawing in workers from the countryside. ${ }^{10}$ Consequently, the attendant rural-urban migration witnessed an influx of migrants to Lagos (Table 1). This rural-urban and transborder migration was facilitated by the improved transportation network (sea, road and railway) in British West Africa. While this phenomenon promoted intra- and interregional trade, it provided an effective conduit for transborder transmission of infectious diseases such as bubonic plague.

Table 1: Population growth in colonial Lagos

\begin{tabular}{|l|r|}
\hline Year & Population \\
\hline 1866 & 25,083 \\
\hline 1891 & 32,508 \\
\hline 1901 & 38,387 \\
\hline 1911 & 73,766 \\
\hline 1921 & 99,700 \\
\hline 1931 & 126,000 \\
\hline 1953 & 230,250 \\
\hline 1960 & 665,246 \\
\hline
\end{tabular}

Source: Laurent Fourchard, 'Lagos and the Invention of Juvenile Delinquency in Nigeria, 1920-60', Journal of African History 47, no. 1 (2006): 117. doi.org/10.1017/S0021853705001660.

The transborder and intra-regional flows continued amidst problems of inadequate infrastructure and poor sanitation. The initial attitude of the colonial officials, who perceived Lagos as nothing more than an entrepôt of trade, underlined an inadequate attention to public health. ${ }^{11}$ As observed by Liora Bigon, ${ }^{12}$ the colonial authorities oscillated between two poles concerning colonial urban space: they were dissatisfied with the overall 'unsanitary' impression of the city of Lagos, but they were not ready to really commit themselves to improvements, as sanitary reforms were not perceived as a legitimate target for public expenditure. This meant that poor sanitation continued in the city. ${ }^{13}$ Urbanisation in Lagos transformed it by the end of the nineteenth century from an agrarian settlement into a city of modern squalor, the result of administrative neglect and an inherent quest for resource exploitation. ${ }^{14}$ Indeed, the colonial Report for 1898 observed of the poor condition of the sewerage system in Lagos that ' $\mathrm{t}$ ] here are hardly any drains, and ... [ $\mathrm{t}]$ here are both land latrines and latrines over the water'. ${ }^{15}$ In the same vein, Ngalamulume observes

10 Akin L. Mabogunje, Urbanization in Nigeria (London: University of London Press, 1968), 327.

11 Robert Gilpin, 'The Lost Tribes: Food Shortage among War Displaced People in Sierra-Leone', West Africa, 10-16 August 1992, 1348; Victor O. Edo and Monsuru Muritala, 'Overcrowding and Disease Epidemics in Colonial Lagos: Rethinking Road and Railway Infrastructure', Nigerian Journal of Economic History 11-12 (2014): 177-9.

12 Liora Bigon, 'Sanitation and street layout in early colonial Lagos: British and indigenous conceptions, 18511900’, Planning Perspectives 20, no. 3 (2005): 247, doi.org/10.1080/02665430500130175.

13 Bigon, 'Sanitation and street layout', 247.

14 Spencer H. Brown, 'Public Health in Lagos, 1850-1900: Perceptions, Pattern, and Perspectives', International Journal of African Historical Studies 25, no. 2 (1992): 338, doi.org/10.2307/219390.

15 Colonial Reports—Annual No. 284. Lagos. Report for 1898 (London: HMSO, 1899), 15. 
that the process of growth in Saint Louis, Senegal, 'in the context of international commerce and travel', created unsanitary conditions favourable for the outbreak of infectious diseases in the early colonial era. ${ }^{16}$

In the face of rapid flows of people and commodities across British West Africa, the environmentally degraded landscape of colonial Lagos was thus unwittingly prepared to harbour a pathogenic reservoir for impending epidemics. The shipment of goods across borders ensured the movement of infectious diseases to new areas. The speed of these processes, due to improved technology, facilitated the spread of epidemics. It is not surprising, therefore, that the index case has been traced to the kola nut trade between the Gold Coast and Nigeria during the period 5 May to 17 June 1924, when quarantine against the Gold Coast ports was raised. ${ }^{17}$ The period 1924 to 1931 saw a continuous outbreak of the epidemic, with a total of 1,947 cases and 1,813 deaths in Lagos (Table 2)..$^{18}$ The population of Lagos in 1921 was 99,700 , rising to 126,000 by $1931 .^{19}$ Thus, with a total of 1,813 people dying, the case fatality rate attributable to bubonic plague in the city amounted to 94.02 per cent from 1924 to 1931 . While this data on plague morbidity and mortality represents only officially recorded cases based on laboratory observation, these official figures provide a guide to the pattern of the outbreak.

Table 2: Plague morbidity and mortality in Lagos, 1924-31

\begin{tabular}{|l|r|r|r|}
\hline Year & Plague cases & Deaths & Mortality rate \\
\hline 1924 & 414 & 343 & $82.8 \%$ \\
\hline 1925 & 104 & 88 & $84.6 \%$ \\
\hline 1926 & 497 & 476 & $95.8 \%$ \\
\hline 1927 & 155 & 151 & $97.4 \%$ \\
\hline 1928 & 519 & 509 & $98.0 \%$ \\
\hline 1929 & 188 & 176 & $93.6 \%$ \\
\hline 1930 & 65 & 65 & $100.0 \%$ \\
\hline 1931 & 5 & 5 & $100.0 \%$ \\
\hline Total & 1947 & 1813 & \\
\hline
\end{tabular}

Source: 'Annual Medical and Sanitary Report, Nigeria' (1931), 27; 'Annual Report, Nigeria, No. 1710' (1934), 21. NAl.

16 Kalala I. Ngalamulume, 'Coping with Disease in the French Empire: The Provision of Waterworks in Saint Louis Du Senegal, 1860-1914', in Environmental History of Water: Global Views on Community Water Supply and Sanitation, ed. P. S. Juuti, T. S. Katko and H. S. Vuorinen (London, IWA Publishing, 2007), 148.

17 'Plague in Lagos. Reference Cable from Secretary of State', From the Deputy Director of Sanitary Service, Lagos, to the Director of the Medical and Sanitary Service, Lagos. Memorandum No. 333/DMS/24 of 30 July (1924), 1. CSO 2613001 Vol. I, NAI.

18 'Annual Medical and Sanitary Report' (1931), 27; 'Annual Report, Nigeria' (1927), 21. NAI.

19 Fourchard, 'Lagos and the Invention of Juvenile Delinquency in Nigeria, 1920-60', 117. 
Furthermore, important environmental determinants of plague morbidity are climatic conditions and their effects on the vector-rodent (flea-rat) population. It has been scientifically proven that plague bacilli flourish best in a temperature range of about $15^{\circ} \mathrm{C}$ to $27^{\circ} \mathrm{C}$ in conjunction with a certain degree of atmospheric dryness. ${ }^{20}$ Thus, favourable climatic conditions for breeding encouraged the spread and transmission of plague, especially when the disease was already epizootic among the rat population, as was the case in colonial Lagos. ${ }^{21}$ In the final analysis, the climatic variances show humid atmospheric conditions conducive for plague reproduction..$^{22}$ In combating the epidemic, myriad public health interventions were attempted.

\section{Plague and colonial interventions: The case of environmental sanitation}

In managing the plague epidemic of 1924-31, the colonial authorities responded through several public health measures, including transborder disease surveillance, quarantine measures, medical healthcare and environmental sanitation. These measures were designed to contain the further transmission of plague into Lagos. In the implementation of transborder epidemic surveillance, passengers arriving in Lagos through the port were landed at the quarantine station and their clothing and bedding disinfected with Clayton gas. ${ }^{23}$ Boxes with clothing were disinfected with a few ounces of formalin. While rat guards and tar were applied to the mooring ropes of all vessels from Gold Coast ports, it was not considered necessary to fumigate these ships. ${ }^{24}$ In Lagos, all ships coming alongside the wharves affixed rat guards, tarred their cables, and whitewashed their gangways, lighting them at night. ${ }^{25}$ These measures were considered necessary to prevent sanitary and screening

\footnotetext{
20 John F. D. Shrewsbury, A History of Bubonic Plague in the British Isles (Cambridge: Cambridge University Press, 2005), 3.

21 The atmospheric mean temperature of the port city in 1923 was $27.2^{\circ} \mathrm{C}$; in $1924,27.4^{\circ} \mathrm{C} ; 1925,26.5^{\circ} \mathrm{C}$; $1927,26.8^{\circ} \mathrm{C} ; 1928,26.9^{\circ} \mathrm{C} ; 1929,26.6^{\circ} \mathrm{C} ; 1930,27.2^{\circ} \mathrm{C} ; 1931,27.5^{\circ} \mathrm{C}$; and in $1932,26.7^{\circ} \mathrm{C}$. Sources of statistics are: Blue Book, Nigeria (Lagos: Government Printer, 1923), 531; Blue Book, Nigeria (Lagos: Government Printer, 1924), 575; Blue Book, Nigeria (Lagos: Government Printer, 1925), 554; Blue Book, Nigeria (Lagos: Government Printer, 1926), 572; Blue Book, Nigeria (Lagos: Government Printer, 1927), 602; Blue Book, Nigeria (Lagos: Government Printer, 1928), 632; Blue Book, Nigeria (Lagos: Government Printer, 1929), 628; Blue Book, Nigeria (Lagos: Government Printer, 1930), 643; Blue Book, Nigeria (Lagos: Government Printer, 1931), 645; Blue Book, Nigeria (Lagos: Government Printer, 1932), CC7.

22 'Meteorological Observations made in Nigeria during the year 1927', in 'Annual Report, Nigeria' (1927); 'Meteorological Observations made in Nigeria during the year 1929', in 'Annual Report, Nigeria' (1929). NAI.

23 'Plague in Lagos'. From the Deputy Director of Sanitary Service, Lagos, to the Director of the Medical and Sanitary Service, Lagos, Memorandum No. 333/DMS/24 of 31 July (1924), 2. CSO 2613001 Vol. I, NAI.

24 'Plague in Lagos'. From the Deputy Director of Sanitary Service, Lagos, to the Director of the Medical and Sanitary Service, Lagos, Memorandum No. 333/DMS/24 of 31 July (1924), 3. CSO 2613001 Vol. I, NAI.

25 'Plague in Lagos'. From the Deputy Director of Sanitary Service, Lagos, to the Director of Medical and Sanitary Service, Lagos. Memorandum No. 333a/DMS/24 of 10 September (1924), 3. CSO 2613001 Vol. II, NAI.
} 
evasion at the port. ${ }^{26}$ Security agents were deployed to prevent persons boarding or leaving ships without a pass from the Port Health Officer. Third-class passengers travelling overseas were medically examined before embarkation, and their clothing and baggage disinfected when this was considered necessary. ${ }^{27}$ This pattern of transborder surveillance, screening and disinfestation continued throughout the outbreak from 1924 to 1931. Increased powers were given to the Port Health Officers under the quarantine regulations of 1925 and the Quarantine Ordinance of 1926, which empowered them to carry out preventive measures, 'whether the port was actually declared to be in quarantine or not'. ${ }^{28}$ While the transborder disease surveillance was useful in the prevention of plague transmission through the port of Lagos, the porosity of West African land borders challenged its effectiveness. Indeed, while West African boundaries symbolised state power, transborder flows continued as a result of ongoing informal social groupings and networks. The case of arbitrary borders drawn across well-established cultural areas of West Africa undermined official control. ${ }^{29}$ This scenario eroded the effectiveness of these epidemic control measures, as informal transborder migration occurred on a daily basis across the porous land borders of the region.

The quarantine measures involved the encampment for observation at the Infectious Diseases Hospital of people who had been in contact with cases of plague. When an infected area was designated, the affected blocks of buildings in which the case had occurred were surrounded by a corrugated iron fence sunk into the street. ${ }^{30}$ The Public Works Department constructed bush houses in the Infectious Diseases Hospital compound as temporary accommodation for the swelling numbers who had been in contact with plague victims. Temporary sanitary inspectors were employed to relieve the stressed experienced officers working in the affected areas. ${ }^{31}$ A camp was arranged in which all passengers who desired to leave the infected area might be kept under observation for five days before departure. Each was given

\footnotetext{
26 'Plague in Lagos'. From the Deputy Director of Sanitary Service, Lagos, to the Director of the Medical and Sanitary Service, Lagos, Memorandum No. 333/DMS/24 of 12 August (1924), 6. CSO 2613001 Vol. I, NAI.

27 'Plague in Lagos'. From the Deputy Director of Sanitary Service, Lagos, to the Director of Medical and Sanitary Service, Lagos. Memorandum No. 333a/DMS/24 of 10 September (1924), 1-2. CSO 2613001 Vol. II, NAI; 'Plague in Lagos'. From the Deputy Director of Sanitary Service, Accra, to the Director of Medical and Sanitary Service, Accra. Memorandum No. 1815/27/19 of 23 September (1924), 1. CSO 2613001 Vol. III, NAI. 28 'Annual Medical and Sanitary Report' (1926), 33; 'Annual Medical and Sanitary Report' (1929), 25-8; 'Annual Medical and Sanitary Report' (1927), 26-9; 'Annual Medical and Sanitary Report' (1929), 25-9; 'Annual Medical and Sanitary Report' (1931), 26-8. NAI.

29 Anthony I. Asiwaju, 'Cross-border initiatives and regional integration in West Africa: The Nigerian experience', in Nation-States and the challenges of regional integration in West Africa: The case of Nigeria, ed. Y. Akinyeye (Paris: Karthala, 2010), 137; Olukayode A. Faleye, 'Regional integration from "below" in West Africa: A study of transboundary town-twinning of Idiroko (Nigeria) and Igolo (Benin)', Regions \& Cohesion 6, no. 3 (2016): 5-13, doi.org/10.3167/reco.2016.060301.

30 'Plague in Lagos'. Memorandum No. 333/DMS/24 of 30 July (1924), 1-2. CSO 2613001 Vol. I, NAI.

31 'Plague in Lagos'. Memorandum No. 333/DMS/24 of 30 July (1924), 2. CSO 2613001 Vol. I, NAI.
} 
an embarkation pass to be delivered to a police officer stationed on the steamer gangway to prevent persons boarding or leaving ships without a pass from the Port Health Officer. ${ }^{32}$

In the interior part of the city, canoes were used for an efficient police water patrol system. Police road patrols were instituted along the Macgregor Canal and at Ikoyi Road Bridge, Onikan Bridge and Five Cowrie Creek bridge, with roadblocks erected as necessary. The implementation of these measures as they applied to the natives was perceived to have been driven by racial prejudices, as local commuters were often sprayed indiscriminately with disinfectants. ${ }^{33}$ These measures were later criticised for obstructing trade flows between Lagos Island and the mainland. ${ }^{34}$ Similarly, quarantine measures in India and South Africa witnessed a related system of racial stigmatisation of the natives, while Europeans were given preferential treatment at disease screening sites such as railway and road-transport stations. ${ }^{35}$ This public health approach taken by the colonial government, especially as it related to quarantine measures and movement restrictions, sent jitters through the local population. This was particularly so due to the high rate of mortality recorded among quarantined victims of plague. For most, the Infectious Diseases Hospital seems to have become a place of no return. ${ }^{36}$ Hence, families began to hide their sick. Information was now difficult or impossible to get, and when a death occurred, many of those who had come into contact with the plague victim ran away and could not be found. Thus, the colonial officials lamented that house to house inspection is difficult on account of the warren-like nature of this part of the town

32 'Plague in Lagos'. From the Director of Sanitary Service, Lagos, to the Chief Secretary to the Government, Lagos. Memorandum No. 333A/DMS/24 of 26 August, (1924), 1-4. CSO 2613001 Vol. I, NAI; 'Plague in Lagos'. From the Deputy Director of Sanitary Service, Lagos, to the Director of Sanitary Service, Lagos. Memorandum No. 333A/DMS/24 of 10 September (1924), 1-9. CSO 2613001 Vol. II, NAI; 'Annual Medical and Sanitary Report' (1929), 25-8; 'Annual Medical and Sanitary Report' (1927), 26-9; 'Annual Medical and Sanitary Report' (1929), 25-9; 'Annual Medical and Sanitary Report' (1931), 26-8. NAI.

33 'Plague in Lagos'. From the Director of Sanitary Service, Lagos, to the Chief Secretary to the Government, Lagos. Memorandum No. 333A/DMS/24 of 26 August (1924), 1-4. CSO 2613001 Vol. I, NAI; 'Plague in Lagos'. From the Deputy Director of Sanitary Service, Lagos, to the Director of Sanitary Service, Lagos. Memorandum No. 333A/DMS/24 of 10 September (1924), 1-9. CSO 2613001 Vol. II, NAI; 'Annual Medical and Sanitary Report' (1929), 25- 8; 'Annual Medical and Sanitary Report' (1927), 26-9; 'Annual Medical and Sanitary Report' (1929), 25-9; 'Annual Medical and Sanitary Report' (1931), 26-8. NAI.

34 'Extract from the minute of Meeting of the Lagos Chamber of Commerce'. Ref. 16316 of 6 March (1926), 1. CSO 2613001 Vol. VII, NAI.

35 Natasha Sakar, 'Fleas, Faith, and Politics: Anatomy of an Indian Epidemic, 1890-1925' (Ph.D. diss., National University of Singapore, 2011), 177-9.

36 The Infectious Diseases Hospital served as an isolation and treatment centre for all official cases of plague discovered in Lagos. We may therefore infer that the hospital must have contributed a significant portion of deaths to the official plague mortality (see Table 2). Although what we know about plague cases at the Infectious Diseases Hospital is based on fragmentary medical statistics, archival evidence points to the overwhelming ineffectiveness of biomedical treatment. For example, a 1926 report on plague mortality rates in the hospital put the death rate at $76.5 \%$. 'Annual Report, Nigeria', (1926), 193. NAI. Clinical case-notes also bear out the largely ineffective treatment of plague victims at the Infectious Diseases Hospital. See, for example, 'Report of Plague in Lagossouthern Nigeria' From the Director Medical Research Institute Yaba to the Director of the Medical and Sanitary Service, Lagos. Report No. 48/M.R.I/24 of 9 September (1924), 2-4. CSO 2613001 Vol. II, NAI. 
and the ease with which the sick can be moved about so as to avoid discovery'. ${ }^{37}$ This was seen as a 'lack of cooperation on the part of the people'. ${ }^{38}$ In response to this public resistance to anti-plague measures, it was decided that while the sick were isolated at the Infectious Diseases Hospital, those who had come into contact with them and had been removed from infected houses should be provided with accommodation until their own dwellings were certified fit for habitation. This scenario ultimately influenced the establishment of the temporary isolation camp of rat-proofed hut accommodation in Ebute Metta, where the occupants of infected houses were placed under observation. ${ }^{39}$ The quarantine measures and movement restrictions were continued throughout the outbreak from 1924 to 1931, and were extended to the neighbouring towns in Ijebu and Abeokuta provinces. ${ }^{40}$

Furthermore, biomedicine was deployed to fight the scourge of bubonic plague. The Infectious Diseases Hospital served as the primary observatory centre for the clinical pathology of plague. Suspected victims and the dead were examined at the hospital. ${ }^{41}$ Haffkine's prophylactic (the plague vaccine) was distributed for inoculation purposes. ${ }^{42}$ By 7 August 1924, four medical laboratories were functional for diagnoses. Medical laboratories at the Medical Research Institute, Yaba, the Public Mortuary, Lagos, the Infectious Diseases Hospital, Ikoyi and the Clinical Laboratory, Lagos, played a significant role in the diagnosis of plague bacilli in victims. All dead bodies were taken to the Public Mortuary for examination. The pathological evaluation of disease transmission was vital to plague control in Lagos. Secondly, smears (bodily fluids) from the glands or lungs of victims, as well as rats caught in the infected area, were sent to the Medical Research Institute, Yaba, or to the clinical laboratory, Lagos, for examination. ${ }^{43}$ Between 9 and 22 September 1924, Dr H. Morrison of the Medical Research Institute, Yaba, examined 208 smears from glands and other organs in connection with 89 post-mortem examinations; 34 of the bodies were infected with bubonic plague. ${ }^{44}$

37 'Annual Medical and Sanitary Report' (1927), 26-9; 'Annual Medical and Sanitary Report' (1929), 25-9; 'Annual Medical and Sanitary Report' (1931), 26-8; 'Annual Report, Nigeria' (1934), 21. NAI.

38 'Plague in Lagos'. From the Deputy Director of Sanitary Service, Lagos, to the Director of Medical and Sanitary Service, Lagos. Memorandum No. 333B/DMS/24 of 4 October (1924), 3. CSO 2613001 Vol. III, NAI. 39 'Plague in Lagos'. From the Deputy Director of Sanitary Service, Lagos, to the Director of Medical and Sanitary Service, Lagos. Memorandum No. 333B/DMS/24 of 4 October (1924), 2-4. CSO 2613001 Vol. III, NAI; 'Plague in Lagos'. From the Deputy Director of Sanitary Service, Lagos, to the Director of Medical and Sanitary Service, Lagos. Memorandum No. 333B/DMS/24 of 8 October (1924), 2. CSO 2613001 Vol. III, NAI. 40 'Extract from the minute of Meeting of the Lagos Chamber of Commerce'. Ref. 16316 of 6 March (1926), 1; 'Annual Medical and Sanitary Report, Nigeria' (1935), 11. CSO 2613001 Vol. VII, NAI.

41 'Plague in Lagos'. From the Director of Sanitary Service, Lagos, to the Chief Secretary to the Government, Lagos. Memorandum No. 333/DMS/24 of 30 July (1924), 1. CSO 2613001 Vol. I, NAI.

42 'Plague in Lagos'. From the Deputy Director of Sanitary Service, Lagos, to the Director of Medical and Sanitary Service, Lagos. Memorandum No. 333/DMS/24 of 31 July (1924), 2. CSO 2613001 Vol. I, NAI.

43 'Outbreak of Bubonic plague in Lagos'. From Medical Research Institute, Yaba, to the Director of the Medical and Sanitary Service, Lagos, Report No.48/MRI/24 of 7 August (1924), 3-4. CSO 2613001 Vol. I, NAI.

44 'Outbreak of Bubonic Plague in Lagos'. From the Medical Research Institute, Yaba, to the Director of Medical and Sanitary Service, Lagos. Report Ref. No. 48/MRI/24 of 24 September (1924), 1. CSO 2613001 Vol. II, NAI. 
The anti-plague vaccine was imported for prophylactic inoculation, 10,000 doses arriving in Lagos fortnightly. ${ }^{45}$ Inoculations were performed in Lagos using the Yersin serum, which was administered in $100 \mathrm{cc}$ doses intravenously. ${ }^{46}$ By 6 November 1924 , about 47,100 people had been inoculated as a result of a house-to-house program. While native people generally raised no objections to such a procedure, in some cases a few residents ran away to evade it. Inoculations were performed in Lagos through the cooperation of African private medical practitioners. However, the colonial authorities observed the limitations of biomedicine in the anti-plague campaign: 'it did not appear as if any treatment tried was very effective'. ${ }^{47}$ This is particularly obvious in the high mean mortality rate of the hospitalised cases, 94.02 per cent between 1924 and $1931 .^{48}$

In Lagos, biomedicine interfered with societal organisation. Biomedicine's weaknesses was obvious in the language barrier separating British medical practitioners and their native patients, which reduced local confidence in the colonial hospitals. Suspicion of Western medicine among locals was heightened by the high mortality rate recorded at the Infectious Diseases Hospital during the outbreak. Also, the perception of illness by Lagosians differed from that of medical practitioners, as the African method of disease aetiology encompasses spiritual divination as well as ethnopharmacological intervention. Both these factors-cultural differences and the seeming ineffectiveness of Western hospitals during the outbreak-compounded to turn local peoples away from such treatment, and to regard it with some suspicion. In comparison, in Asia, biomedical intervention during the plague outbreak in Hong Kong in 1894 presented a similar challenge to that in Lagos. Hong Kong Chinese were fearful of British doctors, so native doctors were allowed into colonial hospitals to administer treatment to plague victims. This anti-Western attitude was reinforced by the high fatality rate ( 77 per cent) among plague patients treated by British doctors. ${ }^{49}$ In Bombay, epidemic plague was conceived in the context of native religious tradition, as Indians sought treatment from the goddess Kali as well as employing traditional remedies and biomedicine, thereby adopting myriad antiplague interventions. ${ }^{50}$

45 'Plague in Lagos'. From the Deputy Director of Sanitary Service, Lagos, to the Director of Medical and Sanitary Service, Lagos. Memorandum No. 333A/DMS/24 of 10 September (1924), 7. CSO 2613001 Vol. II, NAI.

46 'Plague in Lagos', From the Deputy Director of Medical and Sanitary Service, Lagos, to the Director of Medical and Sanitary Service. Memorandum No. 333B/DMS/24 of 8 October (1924), 4. CSO 2613001 Vol. III, NAI.

47 'Annual Medical and Sanitary Report' (1926), 194. NAI.

48 'Annual Medical and Sanitary Report' (1929), 25-8; 'Annual Medical and Sanitary Report' (1927), 26-9;

'Annual Medical and Sanitary Report' (1929), 25-9; 'Annual Medical and Sanitary Report, Nigeria' (1931), 26-8;

'Annual Report, Nigeria, No. 1710' (1934), 21. NAI.

49 Sakar, 'Fleas, Faith, and Politics', 34-5.

50 Sakar, 'Fleas, Faith, and Politics', 34-5. 
The foregoing showcases the serious limitations of transborder epidemic surveillance, quarantine measures and colonial medical intervention in plague control. What was responsible for the extermination of the plague chain in 1931? This paper set out to answer this question from the perspective of environmental change and transformation, as framed by nature-culture interaction over time. As a zoonotic disease, plague relies on reservoirs, including fleas and rodents, for its survival over time. ${ }^{51}$ The association of epidemics with dirt is well established. In Europe, before the emergence of the germ theory in the nineteenth century, infectious diseases had been associated with foul air and animal droppings, filth and decay- 'miasmas'. ${ }^{52}$ These pre-scientific ideas about disease manifestation had their analogues in Africa. For instance, the precolonial Yoruba culture emphasised the connection between dirt and disease. This is boldly stamped in the various sociocultural traditions of the people. It is stipulated in the Ifa oracular literature (a primary source of Yoruba history). The part of the If $a$ oracular chant dealing with the nexus between personal hygiene and sickness is the sixteenth chapter, known as Orangun Meji, and its seventh verse. According to this ancient oral tradition:

A ki i f'iti ju karun, A si maa f'itiju ko o; A dia fun Afinju, Ti n lo yan obun lale. Eekana owo pente; Pente pente isale. Bi a lobun lobinrin, A o lee jeru mo; A dia fun Esu aiwe, Ti yoo mu obinrin sa lo, Ni'ile Agbonmeregun. Nje, alade mo n we o, Kuunsu, Alade mo n we o, Kuunsu. ${ }^{53}$

This If $a$ verse discusses the link between poor hygiene or sanitation and the outbreak of disease. The Ifa divinity rebuked poor hygiene and affirmed the inevitable outbreak of epidemics in an unsanitary environment. Personal hygiene could be evaluated through the sanitary state of fingernails and private parts, as well as the sequence of bathing. This verse emphasises that dirty fingernails, unkempt private parts and lack of attention to bodily care constitute a bacteria reservoir and a potent basis for the outbreak of disease. It showcases the important place of women in maintaining proper hygiene and sanitation in their homes, and society in general. This remains the case in traditional Yoruba society, where women are involved in household chores as well as performing social functions such as environmental sanitation (washing of plates and clothes, sweeping and mopping of surroundings) and food preparation, as well as sexual activities.

51 Nicholas A. Boire, Victoria A. Riedel, Nicole M. Parrish and Stefan Riedel, 'Lessons Learned from Historic Plague Epidemics: The Relevance of an Ancient Disease in Modern Times', Journal of Ancient Diseases \& Preventive Remedies 2, no. 2 (2013): 1-2, doi.org/10.4172/2329-8731.1000114.

52 Marianna Karamanou, George Panayiotakopoulos, Gregory Tsoucalas, Antonis A. Kousoulis and George Androutsos, 'From miasmas to germs: A historical approach to theories of infectious disease transmission', Le Infezioni in Medicina 1 (2012): 58-9.

53 Wande Abimbola, Awon Oju Odu Mereerindinlogun (Ibadan: Oxford University Press, 1977), 95. 
A counterpoint to this precolonial social structure in the Yoruba cultural area of Nigeria was the colonial spatial order, which encouraged the attendant migration of mainly menfolk from rural locations and from diverse ethnic backgrounds into the new, rapidly urbanised areas such as Lagos. This effectively altered the traditional demographic balance, as well as the cultural and socio-spatial make-up of the port city. For instance, rapid immigration into the city in the first quarter of the twentieth century led to housing pressure, overcrowding and poor sanitation. ${ }^{54}$ Laurent Fourchard noted that 'pressure in the hinterland, including colonial taxation and agricultural control policies, obliged farmers to migrate to cities, especially in coastal regions' ${ }^{55}$ Demographic imbalance in the face of labour migration characterised by predominantly male actors led to the growth of behaviour risky to health-poor hygiene and prostitution, which bred new forms of infectious diseases. ${ }^{56}$ Indeed, labour migration, dominated by men, distorted the Yoruba sociocultural order. As noted by Kristin Mann, 'the arrival of large numbers of adult male immigrants in [colonial] Lagos created a shortage of women. Those present in the town could alter their domestic situation by leaving one man for another' ${ }^{57}$ In most parts of Sub-Saharan Africa, women were traditionally committed to household chores. ${ }^{58}$ For instance, in Yoruba culture, it was the duty of the woman to keep their house clean. ${ }^{59}$ Hence, the population's gender imbalance and its attendant women's absence in homes weakened household sanitation in Lagos. The aggregate impact of this phenomenon undermined public health in the city during the colonial era.

Based on the scientific understanding of the interaction between human populations and pathogens, sanitary measures were introduced during the plague outbreak in Lagos. The unsanitary condition of the city seems to have provided ideal conditions to help the plague spread. At the outbreak of the epidemic, 205 houses were inspected and 28 of them fumigated, while 1,852 poison baits and 115 rat traps were laid by 31 July $1924 .^{60}$ All houses in the infected area were fumigated with

\footnotetext{
54 Olukoju, 'Population Pressure, Housing and Sanitation', 94-5.

55 Laurent Fourchard, 'Urban Poverty, Urban Crime, and Crime Control: The Lagos and Ibadan Cases, 1929-45', in African Urban Spaces in Historical Perspective, ed. Toyin Falola and Steven J. Salm (Woodbridge: Boydell \& Brewer, 2005), 294.

56 Saheed Aderinto, 'Of Gender, Race, and Class: The Politics of Prostitution in Lagos, Nigeria, 1923-1954', Frontiers 33, no. 3 (2012): 75-7, doi.org/10.5250/fronjwomestud.33.3.0071.

57 Kristin Mann, 'Women, Landed property, and the accumulation of wealth in early colonial Lagos', Signs 16, no.4, (1991): 702, doi.org/10.1086/494699.

58 Emily Burrill, Richard Roberts and Elizabeth Thornberry, 'Domestic violence and the Law in Africa', in Domestic violence and the Law in colonial and postcolonial Africa, ed. E. Burrill, R. Roberts and E. Thornberry (Athens: Ohio University Press, 2010), 10; Chantal Epie and Afam Ituma, 'Working hours and work-family conflict in the institutional context of Nigeria', in Work-family interface in Sub-Saharan Africa, ed. Z. Mokomane (New York: Springer International Publishing, 2014), 61.

59 N. A. Fadipe, The Sociology of the Yoruba (Ibadan: Ibadan University Press, 1970), 87.

60 'Plague in Lagos'. From the Director of Sanitary Service, Lagos, to the Chief secretary to the Government, Lagos. Memorandum No. 333/DMS/24 of 31 July (1924), 1. CSO 2613001 Vol. I, NAI.
} 
sulphur. After fumigation, they were sprayed with a mixture of tar oil and kerosene. ${ }^{61}$ The disinfection of houses and the quarantining of their inhabitants were carried out alongside claims for compensation for property alleged stolen during the sanitary operations. ${ }^{62}$ The bodies of all the dead in the infected area were examined postmortem, and similar action was taken in the case of all sudden or suspicious deaths in other parts of Lagos. ${ }^{63}$

The nodes and hubs of colonial Lagos' transportation system became a theatre of sanitary warfare against the scourge of the plague. In this respect, Denton Bridge was strategic in the prevention of plague transmission to the mainland. Sanitary measures were adopted to safeguard the city at geostrategic points. At Denton Bridge, outgoing cars were stopped and all passengers examined, their underclothing receiving a light spray of kerosene emulsion, unless they already had naphthalene or kerosene in their clothes. All bundles or boxes of clothing and bedding were inspected. If they contained naphthalene, they were passed; if not, they were sprayed. These measures were applied at the southern terminus of the Western Nigerian Railway at Iddo Island. Passengers leaving the infected area by rail from Iddo station were examined at a barrier, receiving the same treatment as those at Denton Bridge, as well as a pass which had to be presented in order to get a railway ticket. ${ }^{64}$

In Lagos, rat destruction carried out between 1924 and 1931 showed the prevalence of Rattus norvegicus in the port city. The rats caught in the infected areas were examined at the Medical Research Institute, Yaba. By 5 August 1924, out of 100 rats caught in the operation, five were found to be infected with plague. ${ }^{65}$ By 4 October 1924, the deputy director of the Sanitary Service confirmed that Lagos had been infested by infected rodents, as they had been caught in widely separated parts of the town, from Carter Bridge to Oke Suna Street, and as far south as Broad Street. ${ }^{66}$ Rat destruction, as part of the sanitary measures, was carried out by means of traps and poison. Rat-catching gangs were instituted and gradually expanded. Barium carbonate was used as a poison in three-grain doses made up with a preparation of maize. The ratting gangs were provided with buckets of disinfectant labelled with the name of the area where they had been found, and the rats had a cloth tag attached to

61 'Plague in Lagos'. From the Deputy Director of Sanitary Service, Lagos, to the Director of Medical and Sanitary Service, Lagos. Memorandum No. 333/DMS/24 of 31 July (1924), 1. CSO 2613001 Vol. I, NAI.

62 'Compensation Board: Plague Infection'. From the Director of Medical and Sanitary Service, Lagos, to the Chief Secretary to the Government, Lagos. Memorandum No.570/DMS/24 of 23 December (1926), 1-2. CSO 2613001 Vol. VIII, NAI.

63 'Plague in Lagos'. From the Deputy Director of Sanitary Service, Lagos, to the Director of Medical and Sanitary Service, Lagos. Memorandum No. 333/DMS/24 of 13 August (1924), 1. CSO 2613001 Vol. I, NAI.

64 'Plague in Lagos'. From the Deputy Director of Sanitary Service, Lagos, to the Director of Medical and Sanitary Service, Lagos. Memorandum No. 333A/DMS/24 of 10 September (1924), 4. CSO 2613001 Vol. II, NAI.

65 'Plague in Lagos'. From the Director of Sanitary Service, Lagos, to the Chief Secretary to the Government, Lagos. Memorandum No. 333/DMS/24 of 5 August (1924), 1. CSO 2613001 Vol. I, NAI.

66 'Plague in Lagos'. From the Deputy Director of Sanitary Service, Lagos, to the Director of Medical and Sanitary Service, Lagos. Memorandum No. 333B/DMS/24 of 4 October (1924), 2. CSO 2613001 Vol. III, NAI. 
them which indicated more precisely where they had been caught. The rats caught in the operation were of the species Rattus rattus and $R$. norvegicus, the former being in the majority. Some of them were found infected with plague bacilli. ${ }^{67}$

Initially, rat destruction did not receive the anticipated public assistance, even with an offer of twopence per rat caught. Cases were reported where baskets or other receptacles were inverted over traps set in premises by the official rat-catchers, to prevent rats being caught. The occupiers had feared should infected rats be caught, their houses would be liable to disinfection and they themselves quarantined. ${ }^{68}$ The increasing awareness of the link between the infestation of Lagos with plague bacilli and the consequent spread of the disease through rat-human contact led to improved cooperation between the colonial authorities and the natives. ${ }^{69}$ Indeed, in the history of plague control in West Africa, native cooperation constituted a major determinant of the efficacy of public health measures. For instance, Myron Echenberg's examination of the pattern of bubonic plague in colonial Senegal shows how the sociocultural approach of the locals to the epidemic impacted on the efficacy of colonial interventions. Echenberg noted that in 1914, Africans resisted public health policies in the streets of Senegal, and the French containment strategies failed. However, by 1944 the outbreak had been successfully controlled by applications of the new insecticide DDT, the use of antibiotics and the cooperation of locals. ${ }^{70}$

By 1929, the anti-plague work in Lagos was organised under the Medical Officer of Health, who oversaw the routine district work of house-to-house inspections. Special anti-plague labour gangs, each consisting of two self-contained units with headmen and equipment, were allotted to each of the five districts in the town. A senior African sanitary inspector under a European inspector in each district closely supervised all the sanitary and anti-plague operations in his district. In this manner, intensive scavenging, ratting, disinfection and enforcement of all regulations and by-laws affecting sanitation was ensured. ${ }^{71} \mathrm{Up}$ to 1931 , the ratting and other usual anti-plague measures were carried out in Lagos and its neighbouring towns and villages of the Ijebu, Egba and Oyo. ${ }^{72}$ Plague control in Lagos from 1924 to 1931 was inherently linked with the decimation of plague reservoirs in the city through sanitary measures, to which the ratting operation and demolition of perpetually

67 'Plague in Lagos: Spraying operations at Denton Bridge'. From the Director of Sanitary Service, Lagos, to the Chief Secretary to the Government, Lagos. Memorandum No. 333A/DMS/24 of 26 September (1924), 6-7. CSO 2613001 Vol. II, NAI.

68 'Plague in Lagos'. From the Deputy Director of Sanitary Service, Lagos, to the Director of Medical and Sanitary Service, Lagos. Memorandum No. 333B/DMS/24 of 8 October (1924), 2. CSO 2613001 Vol. III, NAI.

69 'Annual Medical and Sanitary Report' (1927), 28. NAI.

70 Echenberg, 'Black Death, White Medicine', 15-52.

71 'Annual Medical and Sanitary Report' (1929), 27. NAI.

72 'Annual Medical and Sanitary Report' (1931), 28. NAI. 
rat-infested buildings was vital. While the accurate measurement of rat infestation is impossible to ascertain, the sanitary measures involving rat destruction around human habitation inevitably helped terminate plague infestation.

In the face of the escalation of the epidemic's spread, rat destruction was carried on with energy and with unprecedented help from the general public, who brought on average about 200 rats daily to the rat stations which had been established. Infected rats were caught nearer and nearer towards the south of the city and, as this continued, human cases tended to occur in the most unsanitary huts and houses. ${ }^{73}$ Subsequently, rat infection extended south of Broad Street. Infected rats were also caught in Marina and Iddo. ${ }^{74}$ The sustenance of plague among rats in the city advanced: in 1927 an infection index of 1.07 per cent was reported. This later declined in 1929 to 0.54 per cent. ${ }^{75}$ More than any other anti-plague method, sanitary measures involving the elimination of the plague foci were central to the eradication of the epidemic by 1931 . Thus, the urban planning strategy of the postplague years, which involved slum clearance, was anchored on this reality. The case of Ebola in West Africa presents a similar scenario, in which the outbreak began in the wild animal population and was transmitted to humans due to poverty and poor infrastructure. ${ }^{76}$ Indeed, the worst-affected areas in Liberia, Sierra Leone and Guinea are essentially rural; otherwise, the disease was associated with urban squalor and slums lacking sewerage and good-quality housing. In essence, both plague and Ebola are diseases of underdevelopment emanating from the interaction between the human population and the natural environment. This historical trend brings to the fore the importance of social equity and effective environmental management in the West African public health system.

\section{Conclusion}

This paper reveals how globalisation and colonialism impacted on Lagos' disease environment in the first quarter of the twentieth century. European colonisation and its attendant urbanisation transformed the local environment in the face of unprecedented immigration that was stimulated by new opportunities for high

73 'Plague in Lagos: Report for the fortnight ended 21st October, 1924'. From the Deputy Director of Sanitary Service, Lagos, to the Director of Medical and Sanitary Service, Lagos. Memorandum No. 333B/DMS/24 of 22 October (1924), 1-2. CSO 2613001 Vol. III, NAI.

74 'Plague in Lagos: Report for the fortnight ended 4th November, 1924'. From the Deputy Director of Sanitary Service, Lagos, to the Director of Medical and Sanitary Service, Lagos. Memorandum No. 333C/DMS/24 of 6 November (1924), 1. CSO 2613001 Vol. III, NAI.

75 'Annual Medical and Sanitary Report' (1929), 27. NAI.

76 Katendi Changula, Masahiro Kajihara, Aaron S. Mweene and Ayato Takada, 'Ebola and Marburg virus diseases in Africa: increased risk of outbreaks in previously unaffected areas?', Microbiology and Immunology 58, no. 9 (2014): 483-90, doi.org/10.1111/1348-0421.12181; Robin J. Evans and Musa Mammadov, 'Dynamics of Ebola epidemics in West Africa 2014', F1000Research 3, no. 319 (2014), doi.org/10.12688/f1000research.5941.1. 
wages and commerce. The outbreak has been traced to improved communication networks that facilitated the kola nut trade between Kumasi in the Gold Coast and Lagos. This was essentially the result of transporting infected persons, rodents and fleas, as well as contaminated cargoes. The rise in the population of Lagos and the evolution of urban slums with poor sanitary and infrastructural facilities created an environment conducive to pathogenic infestation. This is obvious in the case of the Oko Awo, where the outbreak was first recorded.

This study unveils the limitation of transborder disease surveillance, quarantine measures and medical interventions in plague control. Essentially, it reveals the vital role of sanitation in the fight against plague in Lagos. It shows how sanitary measures, especially ratting operations, helped reduce plague foci in the city, thereby terminating the epidemic chain by 1931 . This discovery brings to the fore the central place of environmental management in public health and epidemic control in West Africa. Among others, the lessons of plague control from 1924 to 1931 are relevant to the management of emerging infectious diseases such as Ebola in the region. 
This text is taken from International Review of Environmental History, Volume 3, Issue 2, 2017, edited by James Beattie, published 2017 by ANU Press, The Australian National University, Canberra, Australia.

dx.doi.org/10.22459/IREH.03.02.2017.05 